\title{
Commodity Readers: an Introduction to a Frame for Reading
}

\author{
Simon R. Frost
}

In the history of human conduct, the studied readings of national philology form only a fragment, for reading does not always comprise literary critical interpretation and aesthetic judgement. In the custody of other habits, other types of reading are clearly possible. So what kinds of other readings have occurred? Empirical studies have begun investigating reading evidence, gathered in searchable databases, but they remain largely evidential fragments and for the most part remain mute on the performance of 'a reading'. To conduct a reading of a work, no matter how alternative, might risk sending the empiricist back into the domain of criticism, thus staking out the 'reading' as the fault line that separates histories of the book from comparative literary study.

One alternative discourse to scholarly aesthetics is economics. Exclusion of the moneyed interest appears in the aesthetic theorisation of Kant, its repercussions flowing into Adorno and Horkheimer's accusations of $1944 .{ }^{1}$ The apparent opposition appears as a cause célèbre in much subsequent criticism of the Frankfurt school. ${ }^{2}$ Ignoring for a moment that all texts published by the booktrade involve a commercial element, it is still reasonable to assert that any reading undertaken within a discursive frame of economics should reproduce an experience of the text ungoverned by accepted literary-critical criteria. In this chapter, therefore, I will consider one such way of reading, which I have coined 'a commodity reading'. I will examine its historical pertinence, how it differs from reception theory, how commodity decoding contrasts to literary hermeneutics, and the relevance of free indirect discourse and framing. I will introduce the idea of 'goods' or satisfactions the commodity reader can decode when treating the work as a bibliographic and linguistic resource. Finally, I 
offer a résumé of a commodity reading of George Eliot’s Middlemarch (1871-72). However, rather than remain within theory, I explore the commodity reading's plausibility by comparison: to the few extant remarks of contemporary readers, and to the satisfactions foregrounded in rival print products as well as rival spin-off products, from Eliot bicycles to Eliot ketchup. ${ }^{3}$ Besides the literary-aesthetic value of Middlemarch, concomitant commodified appeals can be identified that are exploited by the material book and by other rival products, explaining why such a work finds an enduring appeal in a commodity culture. The commodity reading, therefore, is only useful in that it provides a plausible articulation of appeals made by a group of products and that it offers a fragment of theorisation back to a larger empirical project.

\section{Historical pertinence}

The term ‘commodity’ is extremely specific. As Arjun Appadurai indicates, commodities predate industrial and even monetarised societies. A commodity, 'refer[s] to things that, at a certain phase in their careers and in a particular context, meet the requirements of commodity candidacy'; this applies equally to the necklaces and arm-shells used in the kula exchange system of the Western Pacific, 'the best documented example of a non-Western, preindustrial, nonmonetized, translocal exchange system', as to any item from a class of industrialised manufactured goods. ${ }^{4}$ To paraphrase Appadurai, the question is not 'what is a commodity?' but what contexts justify the term 'commodification'.

For commodification, all that is required is material, human intervention and exchange. Material must be worked upon and exchanged in an economy, which can be characterised in any number of ways, such as a barter economy or a mercantile or free-trade economy. Marx’s definition of the commodity follows these lines, in proposing that the value commodities supply to be the disembodied labour that has gone into the commodity's 
production; all of which is a simplification of Marx's discussion of commodities in Capital. ${ }^{5}$ All kinds of published writing, therefore, from incunabula to T.S. Eliot qualify as commodities.

Commodity culture, however, although conceptually possible, is hard to imagine without industrialisation. Thomas Richards finds commodity culture emerging in Britain from the second half of the 19th century, ${ }^{6}$ a period of increasing affluence among the labouring classes necessary for the large-scale consumption described by W.H. Fraser in The Coming of the Mass Market 1850-1914. ${ }^{7}$ Richards deploys the term first for the Victorian middle classes and later to the labouring classes, when and where enough surplus income and leisure time allow for goods to be purchased. Frank Trentmann, in Free Trade Nation (2008), identifies a period from the late 1870s until the First World War in which the policy of free trade (and consumption in general) was seen as a driving force in a popular democratic project to further the welfare of the British people. Any delineation of commodity culture in Britain, Trentmann notes, places its emergence when 'Free Trade culture played a decisive role in launching a whole new self-conscious interest: the "consumer", 8

Commodity culture is not a useful term for all places and all people; even today, there may be pockets of a subsistence economy where commodity culture has yet to penetrate. The term 'commodity culture' appears in a number of literary studies, including Christoph Lindner's Fictions of Commodity Culture (2003), Catherine Waters' Commodity Culture in Dickens’s Household Words (2008) and Andrew Miller’s Novels Behind Glass: Commodity Culture in Victorian Narrative (1995). ${ }^{9}$ Often the definition is loose: 'By the mid-nineteenth century, the increasing influence of capitalism on everyday life generated in Britain what has come to be known as “commodity culture.”, ${ }^{10}$ However, life influenced by capitalism could easily be discussed in terms of market logic, without recourse to culture. Instead, I propose defining commodity culture as a description for the praxis of a body of people who attempt to 
satisfy private wants through the acquisition of commodities, and not through collective political or religious action. The drive to satisfy human wants, from the most mundane to the most existential, does not lack profundity; commodity culture is the cultural condition in which we read now, whatever the age of the literary work, and, if the prophets of neo-liberal globalisation are to be believed, then quantitively more so. This, then, is the sketch of a boundary within which the commodity reading takes place.

\section{Reception}

Rezeptionsästhetik is inadequate for a commodity reading, for reasons of both materiality and readerships. First, materiality: as textual criticism asks constantly, which version comprises the text? The manuscript, first published or last authorised version, or a subsequently edited scholarly edition? Which document provides an adequate witness for the work? All documents collectively, or each partially, but inadequately by any single one? For a sociology of texts, the material work involves more than lexical signs alone. Format (serialisation, parts, multiple or single volume) and dimensions (its bibliographic code) provide signs, important enough for publishers to invest in, to say nothing of signs accumulated from price, distribution and sales. The gaps that appear between writers, printers, distributors, readers and retailers, as Chartier says, 'is rightly the space in which meaning is constructed, [it] has too often been forgotten not only by classical literary history...but even by Rezeptionstheorie.,11

Rezeptionstheorie also reduces audiences into monolithic ideas of readership. It is illplaced to explain differences of gender, race, and demographics, with the same subtlety sometimes reached by marketing. Unlike a marketing department, reception theory supposes interpretation primarily according to literary history: to interpret text doubly, both as an immediate experience of the text and in interaction with texts previously read. Interpretation becoming a play of literary conventions, and the reader's memory of them, but the 
commodity reader's personal, private experience (Erfahrung of life) is much broader than this frame of literary conventions. A shopper's experience is not something wholly construed by texts (though advertisers wish they were), and the shopper's choice is complex. Some would reduce the audience into poachers and therefore game-keepers, but within the commodity frame we should note, along with G.H. Lewes (George Eliot’s partner) writing anxiously to Blackwood's business manager about the sales of Middlemarch, 'but 'tis an incalculable animal the general reader! ${ }^{, 12}$

\section{Decoding, hermeneutics, and textual unity}

Literary hermeneutics involves interpretation, but to what degree? In Psychonarratology (2003), Bortolussi and Dixon differentiate between degrees of the interpretive act. ${ }^{13}$ A simple cognitive operation to decode a sign differs from discourse processing. Conversely, to process a discourse by generating meanings from interactions between semantic units in a narrative (such as via knowledge discrepancies between narrator, focaliser and focalised) is something different to a sophisticated literary hermeneutic investigation of a formal unity.

Common to all literary hermeneutics is a loyalty to the text as something irreducibly singular, i.e. that the text, however that may be defined, should be considered as a unified whole. Literary interpretation directs itself at a textual unity, whether the signs include paratext or other signs from the material surface, or not (the New Critical variant simply ‘reads’ an autonomous lexical text, freed of historical or biographic contexts). The commodity reader, on the other hand, has no such loyalty to unified form, and is apt to pick and mix. A commodity reading might explain how an individual decodes textual fragments in order to generate not meanings, but a list of potential benefits. When read for the commodity, the work is best described as an open list of benefits perceived by an individual user, rather than a formal unity. 
George Acorn (1911) when unhindered by belt-buckle fights and numbing poverty, found that 'George Eliot in those days I read solely for the story. I used to skip the parts that moralized, or painted verbal scenery, a practice at which I became very dexterous. ${ }^{14}$ George Holyoake, former chartist, cooperative socialist and the last man to be jailed for atheism in Britain, found an unlikely socialist role model in Middlemarch's fictional Caleb Garth. ${ }^{15}$ A diary entry for Sarah Jewett states 'Perhaps I read my Middlemarch too late in the evening but I find very dull stretches in it now and then. But think of Mr Casaubon being but forty five at the time of his marriage!' 16 The key point of such 'readings' is their selectiveness, coupled to a willingness to decode textual fragments according to the contexts of private wants. By judiciously selecting from the same work, Acorn, Holyoake, and Jewett manage to find a good story, a role model for socialism, and gossipy drama respectively.

\section{Free indirect discourse and framing}

Like literary hermeneutics, the commodity reading is also an interpretation. However, the work under consideration is conceived only as a supplier of goods and benefits, quite different from meanings: commodity reading is directed towards an inventory of goods worth acquiring. The list is in principle endless, limited only by the capricious interpretative abilities of actual readers. The experience that determines which item is valuable lies not within texts but within commodity culture, itself primarily a matter of social relations; the identity of valuable items will change along with changes in commodity values. What is valuable in one year, to a particular audience, has a different kind of stability shaped by different kinds of forces, than the values of the literary critical heritage. Both the commodity and critical reading involves hermeneutics, but of a different order.

A key to the ambiguity of fiction - and hence its potential commercial adaptability lies in free indirect discourse. An example of this from Middlemarch comes from a 
description of Joshua Rigg: 'I will add that his finger nails were scrupulously attended to, and that he [Rigg] meant to marry a well-educated young lady (as yet unspecified) whose person was good, and whose connections, in a solid middle-class way, were undeniable. ${ }^{17}$ If this is read as direct reporting of Rigg's intentions then the sentence neutrally imparts information. We are then in a position to establish Rigg as a good sign, if we approve of clean nails, marriage, education and middle-class solidity. If the sentence is decoded as indirect representation, then the narrator comments on Rigg's intentions, possibly in disapproving sarcasm; we therefore discover that Rigg is not supposed to be an index of good. Further collisions between Rigg and other perceived goods throughout the narrative form our opinion. The commodity reading avails itself of Bakhtinian polyphony, although in its reduction of the text to a finite set of positive values, is by rights, anti-Bakhtinian. Free indirect discourse allows the commodity reader to align the text with their own private set of values. The commodity reader reads in their own favour.

Implied in the commodity reading is a conception of framing. ${ }^{18}$ The discursive frame, whether aesthetic or economic, enables the sign to signify in the way it can, what Derrida calls the 'parergon'. ${ }^{19}$ In Framing the Sign (1988), Jonathan Culler describes frames as critical, social and historical contexts, stressing that these contexts are something we produce. ${ }^{20}$ David Lodge argues similarly in 'Middlemarch and the idea of the Classic Realist Text' that 'the meaning of an utterance is determined entirely by its context and the interpretative assumptions that are brought to it. ${ }^{21}$ It should therefore be possible for a reader's interpretation to be enabled by a commodity context, for as Culler notes, 'meaning is context bound but context is boundless. ${ }^{22}$ An example might be the verisimilitude of Eliot's writing, especially the descriptions of her rural Warwickshire childhood. For Lodge's formalist criticism, Eliot's verisimilitude is a key feature in the evolution of realism. In another context (e.g. for someone marooned in an industrial metropolis in the 1870s), Eliot's 
truthfulness to geographic location could signify the rare pleasures of a day in the countryside. In the more recent context of twentieth-century urban sprawl, that same verisimilitude might be processed as nostalgia for a world that never was. The frame shifts meanings. What might happen if the alternative is a commodity frame? What sort of readings would this produce?

The history of economic theory proposes the concept of utility and the notion of goods, that an item or service is deemed good if it satisfies some personal need. William Stanley Jevons (1835-82), co-founder of marginalism (the corner stone of current neoclassical economics), described economics as a calculus of pleasure and pain. Homoeconomicus seeks satisfaction through the acquisition of anything deemed to be good: 'Pleasure and pain are undoubtedly the ultimate objects of the Calculus of Economics. To satisfy our wants to the utmost with the least effort [...] is the problem of Economics. ${ }^{23}$ In normal usage the notion of a good is transferred to solid items, Goods, but the good provided by the product or service does not have to be tangible. The tangible good of 'sitting down' is supplied in a sofa. The good of 'great design', however, is supplied if the sofa is designed by Le Corbusier. The good of a product or service can also be an encouragement, reassurance, inspiration, identity, keys to knowledge, sources of excitement or of wonder or of solace. To apply this insight to a commodity reading, however, requires a sharp left turn into the realm of speculation.

As The Advertiser's Guide to Publicity (1887) puts it, 'The usefulness and value of most things depend, not so much on their own nature, as upon the number of people who can be persuaded to desire and use them. ${ }^{24}$ George Eliot, too, said that the greatest benefit we owe to the artist is the 'extension of our sympathies' ${ }^{25}$ In order to find where the commodityread text seeks to extend our sympathy most, I undertook to search an e-text of Middlemarch and create a register of lexical material, and found discernible patterns. ${ }^{26}$ The term 'good' 
was entered and incidents noted where the term was a direct modifier for a second substantive. A total of some 520 hits were registered: noted when occurring at rates of three or above. Approximately 160 did not modify a second term ('no good because a woman', 'how good of him'). Approximately 50 only appear once (good accent, action, audience, corner-to-sit-in and constitution, etc). Idiomatic usage (good day, good morning) was not registered. For textual scholars, the Gutenberg text is extremely unreliable, presenting a corrupt text, carrying no references for source, etc. It is only a rough guide. However, given that users of Middlemarch may have come to the work through any number of editions or even abridgements, and that the search is purely a speculative experiment for the purposes of illustration, the method is considered acceptable.

Table 1. Lexical Good as a direct modifier in Middlemarch

Good reason (18) [and good understanding (2)] 18 hits

Good humour 15

Good fellow/fellowship

Good nature/natured

Good wife/husband (6) and good brother/father (4): [no good sisters or mothers]

Good birth/blood/family

$\begin{array}{lr}\text { Good cottages/house/housing } & 6\end{array}$

Good food/dinner/drink/cook 6

Good work/day’s work

Good will $\quad 5$

Good news 4 
The most numerous occurrences by far were good reason and good understanding (20 hits); followed by good fellowship, home, wife, husband (poignantly no good sisters or good mothers), cottages, housing, house, work, marriage and so on, as well as good blood and making a good match. I then compiled a second list of 'Good by association and metaphor'.

Table 2. Inventory of goods by association and metaphor

\begin{tabular}{ll}
\hline Gossip & (as character analysis and a response to the \\
& epistemological failure of objectivism) \\
\hline Money & (as a means of payment, not store of wealth \\
& or means of exchange) \\
\hline Food & (nourishing and frugal) \\
\hline Nature and landscape & (but not sublime) \\
\hline Light, fire, brightness and seeing & (vistas of knowledge) \\
\hline Wordless communication & (because words cannot adequately) \\
\hline Effective words and reliable knowledge & (for strategic use and self education) \\
\hline Children & (as source and end-goal of good) \\
\hline Families, extended families and & (but not society) \\
\hline communities & \\
\hline Common values: solidarity, rural &
\end{tabular}


simplicity, and hard work

Good health and true love

(but not unpragmatically)

Improvement (but not reform)

Small things made great

(the importance of small creatures: squirrels)

I compiled the second list by organising positive strings. The narrator positively values 'fine yews’, ‘fine old oaks', ‘grassy hills’ and ‘flowered meadows’ (p.77, p.72, p.55 and p.347). Later, a building’s Old English style is admired, which must have 'children, many flowers, open windows and vistas of bright things to be joyous' (p.72). A string of associations include oak-treed nature, children, joyous homes and Old England. The narrator then tells us that the guardian of Old England's homes is the hard-working Caleb Garth, a man suspicious of intellectual folly. The string expands to include nature, husbandry, homes, family, hard work and scepticism. Such a commodity reading is speculative. Unlike a literary analysis that might select 'goods' in a literary text and present them as thematic keys to the formal structure, the commodity reading offers a loose coalition of decoded positive values, consistent enough to have personal (financial) appeal, with no organizational principle latent to the text.

Table two draws our attention to freedom from debt, food, both frugal and nourishing, endlessly discussing neighbours, rural, provincial, bucolic values, a productive marriage, private improvement, and so on. An intangible good that Middlemarch provides is a piece of worldly advice that urges the 'dear reader' to work hard and pay their debts, to remain intellectually suspicious, and to draw inspiration from nature, glimpsed in the Yeoman's yew trees and grassy meadows. The bundled phrases of Middlemarch speak in praise of good health and a happy marriage. The appeal is to pragmatic conservatism, oriented to family and diligence, and perhaps to merciless honesty, which delights in scepticism and the satisfying 
rejection of absolute knowledge that readers could never enjoy anyway; but Middlemarch also signals a desperate need for aphoristic knowledge in what amounts to self-help.

All of these goods belong not only to Middlemarch the narrative text but to Middlemarch the published product. Eliot's realism is as natural as the careful rural construction on the serial publication's covers, ${ }^{27}$ while its intellectualism to console intellectually-battered readers offered 'wise and witty' sayings that readers could not only mine from her text, but purchase in separate publications. Eliot's commitment to her useful realism, what Caleb Garth called a ‘sacred occupation’ (p.535) is displayed throughout the Imperial vastness of her 8-book task, for example, in the narrator's 'history of man' (p.3), and Dorothea’s delightful 'little colony, where everybody should work' (p.452), and above all, through the security of membership in a Middle community of 'dear readers', addressed as 'we' by the narrator.

Is there however any reason for supposing that actual historic readers may have responded to Eliot and Blackwood's publication in such a manner? Does the commodity reading compare to the satisfactions foregrounded by rival print products and services at the time? A major commodification of goods in Middlemarch and Eliot appears with Blackwood's and Alexander Maine’s two publications of epigrammatic sayings: Wise Witty and Tender Sayings, in Prose and Verse (1872), and The George Eliot Birthday Book (1878). ${ }^{28}$ In 1870, an essay in Tinsley's Magazine wrote that 'the first and chief business of a novel is to give us authentic descriptions of this or that section of the world. ${ }^{, 29}$ Numerous newspaper reviews, such as those in The Times, The Galaxy and the regional Manchester Examiner and Times, praised Eliot's topographical powers. ${ }^{30}$ This quality is also found in Anne Manning’s The Ladies of Bever Hollow (1858), described by John Sutherland as ‘a study of small-town life in the Midlands', ${ }^{31}$ in her Meadowleigh, a Tale of English country life (1863) and Compton Friars: a Tale of English Country Life (1872); Middlemarch was 
subtitled A Study of Provincial Life. Contemporaneously, Ellen Isabelle Tupper had a Country Lane, with Illustrations (1872), there was Lizzie Blake; or Scenes from the Life of a Village Maiden (1872), ${ }^{32}$ while Mrs Henry Wood published tales from her childhood in rural Worcester in the Argosy, (and later in volume form) by 1874.

Bucolic value took centre stage again in 1905 in F.L. Sabatini’s Pictures in Colour of Warwickshire: the country of George Eliot and Shakespeare, which utilised new colour print technologies. $^{33}$ In 1904, William Sharp published Literary Geography, with chapters on 'Brontë Country', 'Scott Land’ and 'The Country of George Eliot'; making capital out of a profound, imaginative landscape inspired by real country, with accompanying drawings. ${ }^{34}$ It was precisely this imaginative country that the London and North Western Railway Company offered through cheap day returns to Eliot's childhood Warwickshire, together with accompanying guides, the George Eliot Country (1900) and Pictures of Nuneaton \& GE Country (1908). ${ }^{35}$

The children's (and thus family) market was broached by two books, by Kate Sweetser (1906) and Amy Cruse (1913) extolling ‘a pretty picture of child life’, the ‘sober harmonies' of English landscape, and 'the long cow shed, where generations of milky mothers have stood patiently'[Figure 1] ${ }^{36}$ This is reiterated in Emily Swinnerton's George Eliot: her early home (1891). ${ }^{37}$ When rural interest became personal, Guy Roslyn’s George Eliot in Derbyshire: a volume of gossip about passages and people in the novels of George Eliot (1876), asserted that Eliot's dramatis personce 'have had a flesh-and-blood existence in the heart of England. ${ }^{38}$ Like-minded titles include William Mottram’s mendacious True Story of George Eliot (1905) ${ }^{39}$ with 86 photographs and illustrations and, following a successful volume for Thackeray, Routledge’s George Eliot Dictionary (1924), giving the real-life sources of Eliot's characters. ${ }^{40}$ L.G. Sequin's Scenes and characters from the works of George Eliot (1888) prominently carried luxury etchings of interpersonal intimacies 
[Figure 2]: a market potential that did not go unnoticed at Blackwood’s. ${ }^{41}$ Their 1901 frontispiece of Middlemarch suddenly eschewed views of rural life (as in all Blackwood publications up until 1874) for drama, namely of Dorothea finding her dead husband in the garden [Figure 3]. The caption reads, 'She laid her hand upon his shoulder and repeated, "I am ready", 42

Having arrived in Warwickshire on the Great Western, you would need to move around, not by public transport but by private emancipation: the bicycle. By the end of the nineteenth-century, J.N. Birch of Nuneaton produced a range of 'George Eliot Cycles’, advertising his machines in the local newspaper [Figure 4]. ${ }^{43}$ Both cheap and private, bicycles liberated movement; they also became emblems of female emancipation. Robert Buchanan’s Bicycle Song (for women) (1898), finishes ‘This magic Wheel I ride/ For now I know God meant me/ To match Man, side by side! ${ }^{44}$ The emancipation was economic, too: 'They [cyclists] had gained the éclat and independence of riding without the expense and trouble of maintaining a stable. ${ }^{45}$ Literary critics have confined themselves to internal structures of Eliot's texts when arguing over Eliot's feminism. Perhaps Birch’s bicyclebuying readers came to firmer conclusions that 'the Eliot' was an emblem, if not of suffragism, then at least of emancipated independence.

\section{R.J. Smith of the George Eliot Sauce Works in Chilvers Coton, Nuneaton, even} produced a ‘George Eliot Mushroom Ketchup’ [Figure 5]. A clue to what was possibly afoot is found in the label [Figure 6]. The leaf and berry motif from the cover design of Middlemarch in serialisation is repeated along with the focus on regional 'leafy' Warwickshire. The label states: 'The ketchup in this bottle is the guaranteed product of real mushrooms, fresh gathered from the meadows surrounding the birthplace of George Eliot'. As Roslyn's book of gossip says in its preface, 'Obvious fidelity to the original sources of 
inspiration is perhaps more remarkably displayed in this writer than in any other author now living.' 46

Sharp and Sabatini, Cruse and Sweetser, Roslyn and Sequin, and of course, John Blackwood, knew that Eliot's intangible value lay in English meadows and the people who flourished there, exactly the same site that was a resource for Smith’s ketchup. Consider Smith’s competitors: HP sauce launched around 1903, again from the Midlands, while Worcestershire sauce sprung from the neighbouring county. Both sauces became worldwide motifs for Englishness, in much the same way as Eliot's Midlands fiction; though in Jevonian economic terms much more effectively.

Literary works - their books and magazine pages, together with their effects on readers - are not solely the custody of national philologies. If we are to understand the relationships between readers and pages, then we must understand what other forces are at play at any particular historical moment. Once those forces are identified, the terms of their discourse can be incorporated into interpretation and thereby generate new theories of reading. There is a methodological advantage in a commodity reading: as a tool to organise large quantities of stubborn empirical material into manageable groups. The commodity reading does not organise solely under the regis of literary criticism or of humanities studies alone, but instead incorporates study from the social sciences, such as economics. Crucially, theorisation of the commodity reading, regardless of whether or not it maintains internal consistency, should not remain immune as a deduced result. The measure of its worth is not in its internal logic but in its interactions with historical data. Its explanation will suffice until a better explanation comes along. What I am suggesting, here, is that the commodity reading provides a place from which to start. 
${ }^{1}$ Cf. Theodor W. Adorno and Max Horkheimer, 'Preface (1944 and 1947)', in Dialectic of the Enlightenment: philosophical fragments (Stanford: Stanford University Press, 2002), pp. xiv-xix.

${ }^{2}$ One such criticism pertinent to the history of reading is found in Karin Littau, Theories of Reading: Books, Bodies and Bibliomania (Cambridge: Polity press, 2006), p. 99.

${ }^{3}$ I owe a debt of gratitude to Mr John Burton of Nuneaton and to Rebecca Walker of the Nuneaton and Bedworth Art Gallery and Museum, for pointing out the Birch and Smith 'Eliot' products, as well as various Eliot-related publications.

${ }^{4}$ Arjun Appadurai, 'Introduction: commodities and the politics of value' in The Social Life of Things: Commodities in a Cultural perspective, ed. by Arjun Appadurai (Cambridge:

Cambridge University Press, 1986) pp. 3-63, p. 6 and p. 18.

${ }^{5}$ Karl Marx Capital: a critique of political economy [Das Kapital 1867-94] trans. Ben Fowkes (Harmondsworth: Penguin, 1976): see Part 1 ‘Commodities and Money’, pp.123244, herein Chapter 1 'The Commodity’, section 3 ‘The Value Form, or Exchange Value’, pp. 138-164 and Chapter 2, 'The Process of Exchange’ pp. 178-187; see also Appendix, ‘Results of the Immediate Process of production’, pp. 949-955.

${ }^{6}$ Thomas Richards, The Commodity Culture of Victorian England (Stanford: Stanford University Press, 1990), pp.7-8, 53, 250, and 258-59.

${ }^{7}$ William Hamish Fraser, 'The Growth of Demand' in The Coming of the Mass Market, 1850-1914 (London: Macmillan, 1981), pp. 3-82.

${ }^{8}$ Frank Trentmann, Free Trade Nation: Commerce, Consumption and Civil Society in Modern Britain (Oxford: Oxford University Press, 2008), p. 13.

${ }^{9}$ Christoph Lindner, Fictions of Commodity Culture: from the Victorian to the Post-Modern (Aldershot: Ashgate, 2003); Catherine Waters, Commodity Culture in Dickens’s Household Words: The Social Life of Goods (Aldershot: Ashgate 2008); Andrew Miller, Novels Behind 
Glass: Commodity Culture and Victorian Narrative (Cambridge: Cambridge University Press, 1995).

${ }^{10}$ Christoph Lindner, Fictions of Commodity Culture: from the Victorian to the Post-Modern (Aldershot: Ashgate, 2003), p. 3.

${ }^{11}$ Roger Chartier [1992], 'Labourers and Voyagers’ in Andrew Bennett, Readers and Reading (Harlow: Longman, 1995) pp. 132-49, p. 138.

${ }^{12}$ Gordon Haight, The George Eliot Letters, volumes 1-9 (New Haven: Yale University Press, 1978) vol. 5, p. 243.

${ }^{13}$ Marisa Bortolussi and Peter Dixon, Psychonarratology: foundations for the empirical study of literary response (New York: Cambridge University Press, 2002), pp. 1-33.

${ }^{14}$ George Acorn, One of the Multitude, with introduction by Arthur C. Benson (London: Heinemann, 1911), pp. 49-50.

${ }^{15}$ George Holyoake, The History of Co-operation (London: T. Fischer Unwin, 1908), p. 348.

${ }^{16}$ Sarah Orne Jewett, in North American Women’s letters and Diaries, Colonial to 1950 (electronic collection) Alexander Street Press, http://alexanderstreet.com/products/nwld.htm [accessed July 2008].

${ }^{17}$ George Eliot, Middlemarch, ed. by David Carroll (Oxford: Clarendon Press, 1986 reprinted 1992), p. 403. Future page references are to this edition, and are included in parentheses in the text.

${ }^{18}$ Defined as a set of related mental data that enables human comprehension: Gerald Prince, A Dictionary of Narratology (Aldershot: Scolar Press, 1988), p. 33.

${ }^{19}$ For a discussion of parergon and sources in Derrida, see John Frow, Marxism and Literary History (Oxford: Basil Blackwell, 1986), pp. 216-224.

${ }^{20}$ Jonathan Culler, Framing the Sign (Oxford: Basil Blackwell, 1988), p. ix. 
${ }^{21}$ David Lodge, 'Middlemarch and the idea of the Classic Realist Text: revised', in Arnold Kettle, The Nineteenth Century Novel (London: Heinemann, 1985), pp 218-238, p. 233.

22 Jonathan Culler, On Deconstruction: theory and criticism after structuralism (London: Routledge, 1983) p. 128.

${ }^{23}$ William Stanley Jevons [1871], Theory of Political Economy, 3rd ed. (London: Macmillan, 1888), Chapter 3, p. 37. See also Preface, v-ix, and Chapter 3, pp. 37-45.

${ }^{24}$ Cited in William Hamish Fraser, The Coming of the Mass Market, 1850-1914 (London: Macmillan, 1981), p. 134

${ }^{25}$ George Eliot [1856], 'Natural History of German Life' in Thomas Pinney, Essays of George Eliot (London: Routledge and Kegan Paul, 1963), pp. 270-71.

\section{Search undertaken of George Eliot, Middlemarch, (Project Gutenberg), online at}

\section{<http://www.gutenberg.org/dirs/etext94/mdmar11.txt> [accessed 14 April 2007].}

${ }^{27}$ See Simon Frost, ““A Handsome Volume”: fra litteraturhistorie til den litterære teksts sociologi’ in Passage: tidsskrift for litteratur og kritik, 57 (2007), 28-45.

${ }^{28}$ Alexander Maine, Wise Witty and Tender Sayings, in Prose and Verse (Edinburgh, London: Blackwood and Sons, 1872) and The George Eliot Birthday Book (Edinburgh, London: Blackwood and Sons, 1878). See also Leah Price, The Anthology and the Rise of the Novel (Cambridge: Cambridge University Press, 2000), pp. 105-156.

29 ‘The Uses of Fiction’ in Tinsley’s Magazine [1870], reproduced in Charles Olmstead, A Victorian Art of Fiction, (N.Y., London: Garland, 1979), vol. 3; p. 8, cited in Price, p. 150, n. 157.

${ }^{30}$ See Anon [Fredrick Napier Broome] 'Review’, The Times, 7 March 1873, reprinted in Stuart Hutchinson, George Eliot: Critical Assessments, vol. 1 (Robertsbridge: Helm Information, 1996), pp.333-337, at p. 333; Anon. [Henry James] 'Middlemarch', Galaxy, 15 March 1873, reprinted in Henry James House of Fiction, (London: Mercury Books, 1962), 
pp. 259-267; the Manchester Examiner and Times, cited in Carol A. Martin, 'Revising

\section{Middlemarch’, Victorian Periodical Review, 25 (1992) 72-78; 77.}

${ }^{31}$ John Sutherland, The Stanford Companion to Victorian Fiction (Stanford: Stanford University Press, 1989), p. 407. Anne Manning, The Ladies of Bever Hollow (London: Richard Bentley, 1858); Anne Manning, Meadowleigh: A Tale of English Country Life (London: 1863); Anne Manning, Compton Friars: A Tale of English Country Life (London: Sampson Low, Marston, Low and Searle, 1872). Ellen Isabelle Tupper, A Country Lane, with illustrations by M.E. Tupper (London, Norwich: 1872).

${ }^{32}$ Anon., Lizzie Blake: or Scenes from the Life of a Village Maiden (London: Religious Tracts Society, 1872).

${ }^{33}$ F.L. Sabatini, Pictures in Colour of Warwickshire, the country of Shakespeare and George Eliot with descriptive notes (London and Norwich: Jarrold \& Sons Ltd, 1905).

${ }^{34}$ William Sharp, Literary Geography (London: Pall Mall 1904).

${ }^{35}$ The George Eliot Country, Official Guide of the London North western Railway Company (Nuneaton and London: The Abbey Press, 1908), and Pictures of Nuneaton and the George Eliot Country (Nuneaton and London: The Abbey Press, 1911). Both guides held at the Nuneaton and Bedworth Museum and Art Gallery, Warwickshire.

${ }^{36}$ Kate Sweetser, Boys and Girls from George Eliot, illustrations by George Alfred Williams (New York: Duffield, 1906), preface: and Amy Cruse, Stories From George Eliot (London: Harrap \& Co., 1913) p. 24-25.

${ }^{37}$ Emily Swinnerton, George Eliot, Her Early Home (London: Raphael Tuck and Sons, 1891).

${ }^{38}$ Guy Roslyn, George Eliot in Derbyshire: a volume of gossip [...], reprinted from London Society with alterations and additions, and an introduction by George Barnett Smith (London: Ward, Lock and Tyler, 1876), p. 8. 
${ }^{39}$ William Mottram, The True Story of George Eliot: in relation to Adam Bede giving the real life history of the more prominent characters (London: Francis Griffiths, 1905).

${ }^{40}$ Isadore Gilbert Mudge, George Eliot Dictionary (London: Routledge, 1924).

${ }^{41}$ Lisbeth Gooch Seguin, Scenes and Characters from the works of George Eliot: a series of illustrations by eminent artists (London: Alexander Strahan, 1888).

${ }^{42}$ George Eliot, Middlemarch, (Edinburgh, London: William Blackwood and Sons, 1901).

${ }^{43}$ My most sincere thanks are given to Mr John Burton of the George Eliot Fellowship and to Rebecca Walker of the Nuneaton and Bedworth Art gallery and Museum, who first brought my attention to the Birch and Smith Eliot products.

${ }^{44}$ Robert William Buchanan, 'Bicycle Song (for women)' in Complete Poetical Works, vol. 2 (London: Chatto and Windus, 1901), p. 350, cited in The Victorian Web,

<http://www.victorianweb.org/authors/buchanan/31.html> [accessed December 2009].

${ }^{45}$ Patricia Marks, Bicycles, Bangs and Bloomers (Lexington: University Press of Kentucky, 1990). p.186.

${ }^{46}$ Roslyn, p.5. 